\title{
Assessing the human health risks from exposure of inorganic arsenic through oyster (Crassostrea gigas) consumption in Taiwan
}

\author{
Chen-Wuing Liu ${ }^{\mathrm{a}, *}$, Ching-Ping Liang ${ }^{\mathrm{b}}$, Feng Mei Huang ${ }^{\mathrm{a}}$, Yu-Mei Hsueh ${ }^{\mathrm{c}}$ \\ ${ }^{a}$ Department of Bioenvironmental Systems Engineering, National Taiwan University, Taipei 106, Taiwan, ROC \\ ${ }^{\mathrm{b}}$ Department of Environmental Engineering and Sanitation, Foo-Yin University, Kaoshiung 831, Taiwan, ROC \\ ${ }^{\mathrm{c}}$ Department of Public Health, School of Medicine, Taipei Medical University, Taipei 110, Taiwan, ROC
}

Received 30 September 2004

Available online 24 August 2005

\begin{abstract}
This study estimated the human health risk associated with ingesting inorganic arsenic through consumption of farmed oysters in Taiwan. Two hundred fifty-four samples of oyster (Crassostrea gigas) were collected from four townships in southwest coastal areas, where $90 \%$ of Taiwan's oysters are produced. The concentrations of total arsenic and arsenic species including $\mathrm{As}(\mathrm{V}), \mathrm{As}(\mathrm{III})$, monomethylarsonic acid (MMA) and dimethylarsinic acid (DMA) were analyzed. The analytical results reveal that the ratio of mean concentration among the four townships of inorganic As to total concentration of As in oysters is approximately $1.64 \%$. The mean concentrations of $\mathrm{As}(\mathrm{III})$ and $\mathrm{As}(\mathrm{V})$ in oysters from the four townships range from 0.071 to $0.145 \mu \mathrm{g} / \mathrm{g}$, and 0.032 to $0.062 \mu \mathrm{g} / \mathrm{g}$ respectively. The estimated target cancer risks (TR), based on a $95 \%$ occurrence probability from ingesting inorganic As by consuming oysters at a rate of $18.6-56 \mathrm{~g} / \mathrm{day}$, range from $1.26 \times 10^{-5}$ to $3.82 \times 10^{-5}$. The probabilities of TR fell within the range $10^{-6}-10^{-4}$, suggesting that inorganic As uptake from farmed oysters is associated with a potential cancer risk. Moreover, a target hazard quotient $(T H Q)$ was used to evaluate the noncarcinogenic risk associated with ingesting inorganic As through oyster consumption at a rate of 18.6-56 g/day. The THQ values based on a $95 \%$ probability of exposure range from 0.071 to 0.214 . All THQ values are below unity, indicating that farmed oyster consumption contributes only a little to the non-carcinogenic risk. Based on the estimation of the TR model, an ingestion rate of $1.6 \mathrm{~g} /$ day is recommended to meet the 95 th percentile of carcinogenic risk, $10^{-6}$, for exposure to inorganic As through the consumption of oysters in Taiwan.
\end{abstract}

(C) 2005 Elsevier B.V. All rights reserved.

Keywords: Oyster; Inorganic arsenic; Health risk assessment

\footnotetext{
* Corresponding author. Tel.: +88622362 6480; fax: +886223639557.

E-mail address: 1cw@gwater.agec.ntu.edu.tw (C.-W. Liu).
} 


\section{Introduction}

Arsenic is a ubiquitous element that is the 20th most abundant in the earth's crust, the 14th most abundant in seawater, and the 12th most abundant in the human body. Humans are exposed to arsenic from various sources, including food, water, air and soil, among others. Previous studies have found that exposure to arsenic may lead to cancers of the liver, kidney, bladder, prostate, lymphoid tissue, skin, colon, lung and nasal cavity (Chen et al., 1992); it may also cause blackfoot disease (BFD) (Ch'i and Blackwell, 1968), ischemic heart disease (Hsueh et al., 1998), hyperpigmentation, hyperkeratosis, diabetes (Tseng et al., 2000), meningioma and other detrimental effects on health (Chan and Huff, 1997). The International Agency for Research on Cancer (IARC) has classified arsenic as a group 1 carcinogen, meaning that sufficient evidence of human carcinogenity exists (IARC, 1980).

BFD is an endemic peripheral vascular disease that is frequently observed among inhabitants in a small coastal area in the southwest of Taiwan, where water in deep wells contains a high concentration of arsenic. Chen et al. (1994) reported total arsenic levels in well water from 470 to $897 \mu \mathrm{g} / 1$ in the hyperendemic BFD area in southwestern Taiwan. Ninety-five percent of all As is inorganic ( $\mathrm{As}(\mathrm{III})$ and $\mathrm{As}(\mathrm{V}))$, and the predominant arsenic species is As(III). The inhabitants have not drunk well water since many epidemiological studies showed that exposure to arsenic was strongly associated with BFD (Chen et al., 1988, 2001). However, groundwater is still utilized in aquaculture (Huang et al., 2003).

Arsenic is present in various chemical forms, all of which can be easily absorbed by aquatic organisms. Arsenic can also accumulate in animal and human food chains (Cullen and Reimer, 1989; Edmonds et al., 1997). Humans are exposed to As from various sources, such as food, water, air and soil; food is the major source of As to which humans are exposed. The U.S. food and Drug Administration (U.S. FDA, 1993) indicated that fish and other seafood account for $90 \%$ of the total As exposure.

Suhendrayatna et al. (2002) also found that freshwater organisms accumulated and transformed arsenic in their bodies. Approximately $90 \%$ of accumulated arsenic was depurated to water. Several arsenic species are present in marine organisms; they include arseno- betaine, arsenocholine, monomethylarsonic acid (MMA), dimethylarsinic acid (DMA), As(V) and As(III) (Edmonds and Francesconi, 1987, 1993; Edmonds et al., 1997; Franceskoni and Kuehnelt, 2002). Arsenical toxicity, determined from the prevalence of carcinogenesis and vascular disorders in an earlier arsenic endemic of southwest coast of Taiwan, follows the order MMA(III) $>\mathrm{As}(\mathrm{III})>\mathrm{As}(\mathrm{V})>$ $\operatorname{MMA}(\mathrm{V})=\mathrm{DMA}(\mathrm{V})$ (Lin et al., 1998). Inorganic arsenic species are more toxic than methyl arsenic species. The U.S. EPA uses inorganic arsenic uptake by various seafood to determine the potential risk to human health (U.S. EPA, 1989, 2004).

Oysters are the most popular shellfish in Taiwan and the major farmed areas are off of the coast of southwest Taiwan, so the As content in oysters has received much attention. Han et al. $(1998,2000)$ used a deterministic risk analysis method to estimate the potential health risks from consuming metals in seafood in Taiwan. Ingesting inorganic arsenic through oyster consumption was associated with a high cancer risk of $5.14 \times 10^{-4}$. Guo (2002) critically examined the work of Han et al. (1998) and concluded that insufficient and improper data and assumptions were used had been responsible for unrealistic results in the latter work.

In this study, inorganic As contents in oysters were comprehensively surveyed to estimate the health risks associated with ingesting inorganic arsenic by consuming oysters. Monthly oyster samples were collected from four townships that supply $90 \%$ of the Taiwanese oyster market, from January to December 2002 (over 12 months). Inorganic As concentrations in oysters were directly measured. The carcinogenic and non-carcinogenic risks to health were evaluated probabilistically which accounted the uncertainty in the risk associated with the concentration of inorganic arsenic in oyster. The results were compared with those of Han et al. (1998) to ensure the validity of the assessed health risk obtained herein.

\section{Materials and methods}

\subsection{Sample collection and analysis}

Local fishermen harvest cultured oysters based on their shell size. When the oyster shell reaches $4 \mathrm{~cm}$ in 
diameter and a wet weight of over $10 \mathrm{~g}$, the oyster is ready to be harvested. Oyster (Crassostrea gigas) samples were collected from southwestern offshore aquaculture farms in Wangkung, Tungshih, Putai and Anpin - four townships that produce $90 \%$ of the oysters in Taiwan (Fig. 1). Oyster samples were purchased monthly at two locations in each township and three oyster samples from each location were analyzed to determine their total As and As species contents. However, purchases were not made in January, February and March in Wangkung; in February or March in Putai, or in January or February in Tungshih. The total number of oyster samples was 254. Oyster samples were frozen while they were transported from the field to the laboratory and stored at $-20{ }^{\circ} \mathrm{C}$ until they were dissected.

A portion of the homogenized samples were freeze-dried for $36 \mathrm{~h}$ and prepared to analyze the total content of arsenic and arsenic species. About $0.5 \mathrm{~g}$ of homogenized freeze-dried samples and 25 $\mathrm{ml}$ of $65 \%$ nitric acid were added to a flask. They were boiled and decanted to allow gases to pass through a condenser and digested for $12 \mathrm{~h}$ until the solution was clear. Total arsenic was analyzed using an electro-thermal atomic absorption spectrometer (AAS) (AA100 Perkin-Elmer Shelton, USA), and a hydride generator (HG) (FIAS 400 Perkin-Elmer Shelton, USA). A $0.5 \% \mathrm{NaBH}_{4}$ in $0.25 \% \mathrm{NaOH}$

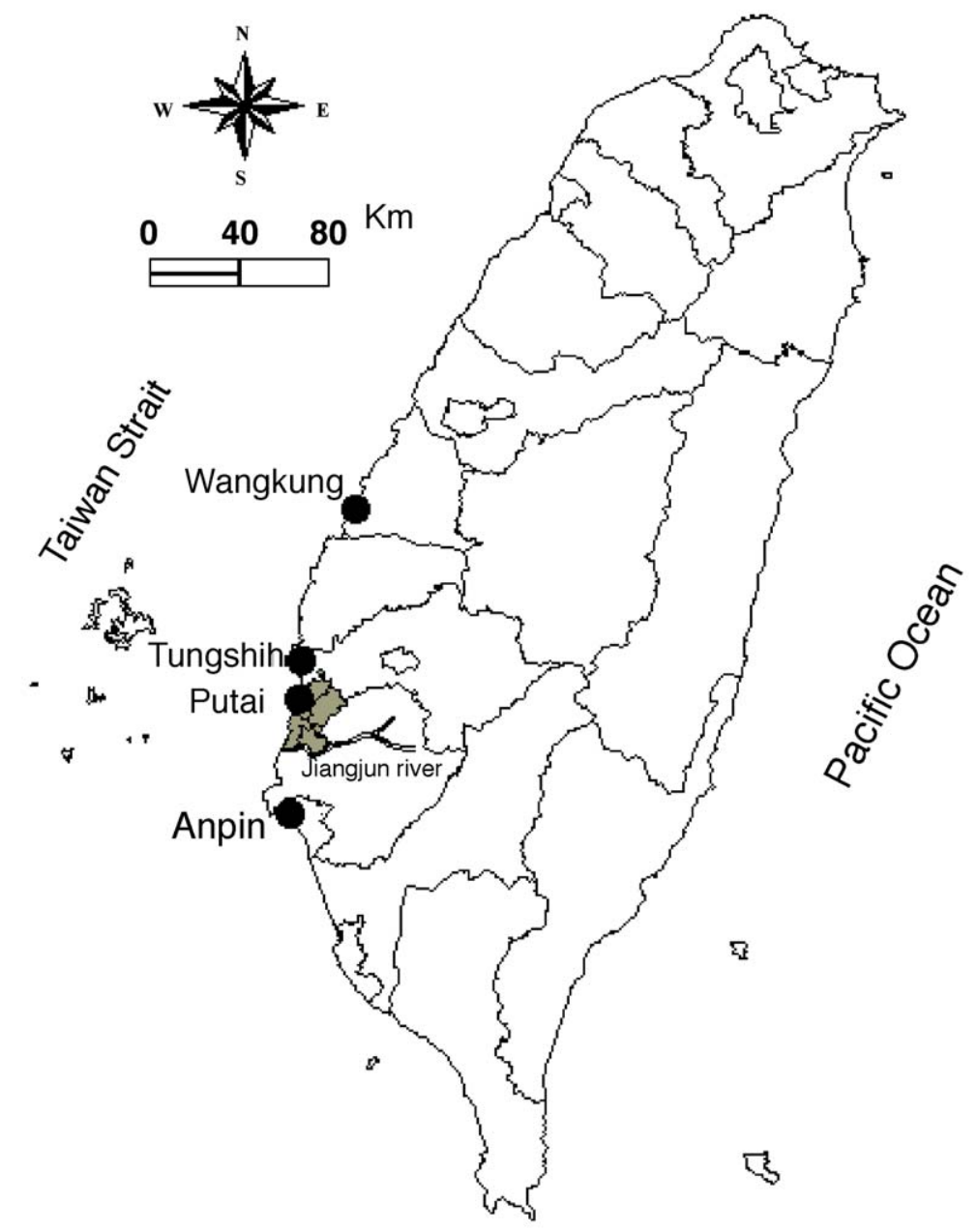

Fig. 1. Oyster sampling locations. The gray region represents the occurrence area of the blackfoot disease. 
and $1 \mathrm{~N} \mathrm{HCl}$ were added to $200 \mu \mathrm{l}$ of a digested sample to reduce the arsenic to arsine. Then, the total arsenic concentrations were determined by HG/AAS.

$1.0 \sim 1.5 \mathrm{~g}$ of freeze-dried oyster and $150 \mathrm{ml}$ of methanol/water solution $(1 / 1, \mathrm{v} / \mathrm{v})$ were placed into a Soxhlet extraction apparatus, modified from that described by Gomez-Ariza et al. (2000) and extracted for $16 \mathrm{~h}$. A methanol extraction tube was designed to remove the methanol when the extraction was complete. After the methanol was removed, the extract was freeze-dried to a powder and re-dissolved in 10 $\mathrm{ml}$ of de-ionized water. The re-dissolved liquids were purified by filtering through $\mathrm{C}_{18}$ cartridges. A highperformance liquid chromatograph, HPLC (Hitachi 7110 , Naka, Japan), equipped with an anion column (Machey-Nagel, Nucleosil, $10 \mu \mathrm{m}, 250 \times 4.6 \mathrm{~mm}$ ) and connected to HG/AAS, was used to separate As(III), As(V), MMA and DMA. The procedures for analyzing As(III), As(V), MMA and DMA followed closely those in our previous study (Huang et al., 2003). Fig. 2 summarizes the method for analyzing total arsenic and arsenic species.

The accuracy of the procedure was validated by the analysis of the standard reference material (SRM) BCR 627 tuna tissue. Total arsenic and DMA concentrations of SRM were $4.9 \pm 0.2 \mathrm{mg} / \mathrm{kg}$ and $1.8 \pm 0.1 \mu \mathrm{mol} / \mathrm{kg}$, respectively, which values were consistent with the certified values of $4.8 \pm 0.3 \mathrm{mg} /$ $\mathrm{kg}$ and $2.0 \pm 0.3 \mu \mathrm{mole} / \mathrm{kg}$, respectively. The detection limits of total arsenic, $\mathrm{As}(\mathrm{III}), \mathrm{As}(\mathrm{V}), \mathrm{MMA}$ and DMA were $0.2,0.4,0.2,0.4$ and $0.3 \mu \mathrm{g} / 1$, respectively. Samples were spiked with arsenic species to calculate the recovery rate in every extraction step and laboratory procedure. The extraction recovery rates of As(III), As(V), MMA and DMA, were $102.7 \pm 4.7 \%$, $104.1 \pm 6.8 \%, 104.7 \pm 6.5 \%$ and $98.0 \pm 7.1 \%$, respectively. The laboratory procedure recovery rates of total As, As(III), As(V), MMA, and DMA were $103.2 \pm 7.1 \%, 100.7 \pm 3.8 \%, 97.2 \pm 4.0 \%, 104.9 \pm$ $4.6 \%$ and $97.2 \pm 4.0 \%$, respectively. The coefficient of variation was used to test the reliability and was less than $5 \%$ for all experiments.

\subsection{Target cancer and non-cancer risk assessment}

Risk assessments are based on assumptions. Assumptions should be clearly stated. They should be carefully validated. Real-life situations should be taken into account to prevent confusion and consequent adverse societal impact.

The Risk Assessment Forum (U.S. EPA, 1988) reevaluated the carcinogenicity associated with ingesting inorganic arsenic. The U.S. EPA Region III RiskBased Concentration Table (U.S. EPA, 2004) present methods for estimating the target cancer risk (TR) and the non-cancer risk (THQ). The risk associated with the carcinogenic effects of inorganic arsenic is expressed as the excess probability of contracting cancer over a lifetime of 70 years. The equation

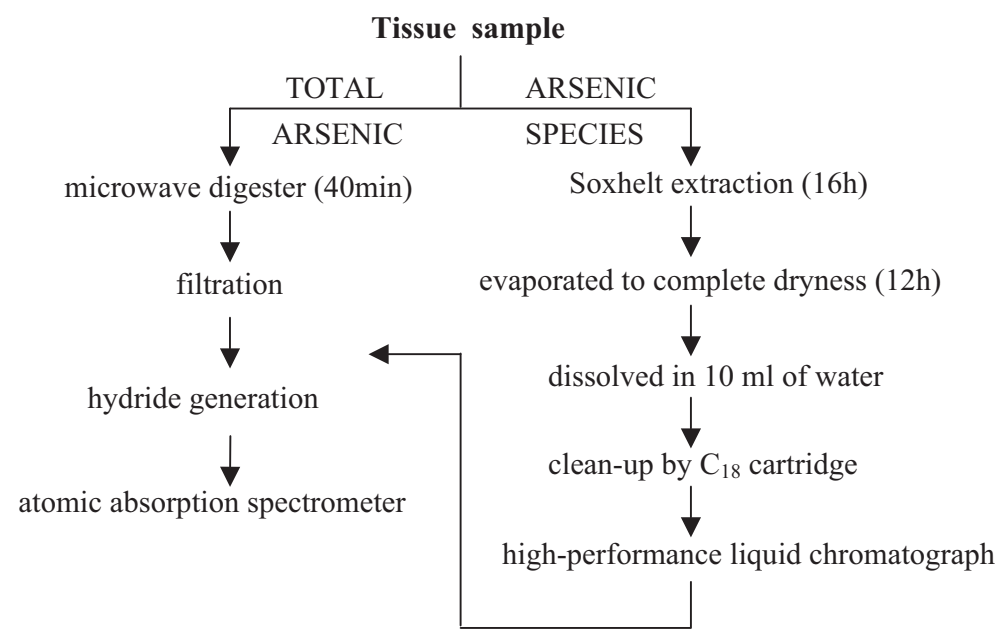

Fig. 2. Analytical method for total arsenic and arsenic species. 
used for estimating the target cancer risk (lifetime cancer risk) is as follows (U.S. EPA, 1989),

$$
\begin{aligned}
\mathrm{TR}= & \frac{\mathrm{EFr} \times \mathrm{ED}_{\text {tot }} \times \mathrm{SFI} \times \mathrm{MCS}_{\text {inorg }} \times \mathrm{CPS}_{\mathrm{o}}}{\mathrm{BW}_{\mathrm{a}} \times \mathrm{AT}_{\mathrm{c}}} \\
& \times 10^{-3}
\end{aligned}
$$

where TR represents the target cancer risk or the risk of cancer over a lifetime; EFr is the exposure frequency (days/year); $\mathrm{ED}_{\text {tot }}$ is the exposure duration (year); SFI is the mass of oyster ingested (g/day); $\mathrm{MCS}_{\text {inorg }}$ is the concentration of inorganic arsenic species in the edible portion of oyster $\left(\mu \mathrm{g} / \mathrm{g}\right.$ wet weight); $\mathrm{CPS}_{\mathrm{o}}$ is the oral carcinogenic potency slope of inorganic arsenic $\left(\mathrm{mg} / \mathrm{kg} /\right.$ day); $\mathrm{BW}_{\mathrm{a}}$ is the body weight of a Taiwanese adult; $\mathrm{AT}_{\mathrm{c}}$ is the averaging time for carcinogens (days), and $10^{-3}$ is the unit conversion factor.

The non-cancer risk was estimated using the hazard quotient method, defined as follows (U.S. EPA, 1989).

$\mathrm{THQ}=\frac{\mathrm{EFr} \times \mathrm{ED}_{\text {tot }} \times \mathrm{SFI} \times \mathrm{MCS}_{\text {inorg }}}{\mathrm{R}_{\mathrm{f}} \mathrm{D} \times \mathrm{BW}_{\mathrm{a}} \times \mathrm{AT}_{\mathrm{n}}} \times 10^{-3}$

where THQ is the target hazard quotient (dimensionless); $\mathrm{R}_{\mathrm{f}} \mathrm{D}$, is the oral reference dose (mg/kg/day); $\mathrm{AT}_{\mathrm{n}}$ is the averaging time for non-carcinogens (day), and $10^{-3}$ is the unit conversion factor.

The exposure duration is 350 days/year for 30 years. An averaging time of 365 days/year for 70 years $\left(\mathrm{AT}_{\mathrm{c}}=25,550\right.$ days $)$ was used to characterize life time exposure for calculating cancer risk. An averaging time of 365 days/year for 30 years $\left(\mathrm{AT}_{\mathrm{n}}=10,950\right.$ days $)$ was used to characterize non-cancer risk. The cancer slope factor and the reference dose for ingested inorganic As are $1.50(\mathrm{mg} / \mathrm{kg} / \mathrm{day})^{-1}$ and $3 \times 10^{-4} \mathrm{mg} / \mathrm{kg} / \mathrm{day}$, respectively, from the U.S. EPA IRIS data base (U.S. EPA, 2003). The average body weight of a Taiwanese adult is $60.5 \mathrm{~kg}$, according to statistical data on 19-65 year old residents in Taiwan (http://www.doh.gov.tw/NewVersion/index.asp). Based on the U.S. EPA (1989) guideline, the ingested dose was assumed to equal the absorbed contaminated dose and that cooking does not affect the contaminants. Additionally, many factors modify the body burden of arsenic, after oysters have been consumed. Therefore, the measurement of arsenic in body fluid is critical to the determination of the health risk from such consumption. This study did not analyze body burden, and the effect of this omission on the estimated human health risk should be noted.

The input parameters in the health risk model have associated uncertainty (Lipton and Gillett, 1991). A range of oyster consumption rates, $18.6-56 \mathrm{~g} /$ day, was adopted to reduce the parametric uncertainty. Moreover, $\mathrm{MCS}_{\text {inorg }}$ in Eqs. (1) and (2) was treated probabilistically. @Risk (Version4.5, Professional Edition, Palisade Corp., USA) software was used to analyze measurements of the concentrations of inorganic arsenic species in oyster and estimated distribution parameters for inorganic arsenic species. A chi-square test was conducted to determine the probability distributions that best fit $\mathrm{MCS}_{\text {inorg. }}$. The Monte Carlo method was used to generate the distribution of inorganic arsenic in oysters from the determined best-fit distributions of concentrations of inorganic arsenic. The determined probability distribution was employed to describe the uncertainty of inorganic arsenic species in oyster. The estimated health risk associated with inorganic As consumed in oysters was expressed as a probability distribution, and the uncertainty in the risk associated with the concentrations of inorganic arsenic in the edible portion of oyster $\left(\mathrm{MCS}_{\text {inorg }}\right)$ was thus accounted for. Other parameters such as the body weight of Taiwanese adult were not treated probabilistically. The objective of this study is to evaluate the health risk from ingesting inorganic arsenic through oyster consumption. If all the parameters were inputted as probability distributions, then the results of the assessment would not allow the individual effects of each parameter to be determined easily and blue the focus of the study. An acceptable risk distribution was defined by constraints on percentiles. The lower end of the range of an acceptable distribution is defined by requiring that the 95th percentile of the risk distribution that must be equal to or lower than $10^{-6}$ for carcinogens and equal to or lower than unity for noncarcinogens.

\section{Results and discussion}

Table 1 presents the monthly measured total As concentration in oysters collected from the four townships. The highest and the lowest total As concentrations in four townships were $22.90 \pm 7.14$ and $4.22 \pm 0.38 \mu \mathrm{g} / \mathrm{g}$ (mean $\pm \mathrm{SD})$. These were measured 
Table 1

Monthly measured total and inorganic As concentrations $(\mu \mathrm{g} / \mathrm{g})$ in oysters from Anpin, Putai, Tungshih and Wangkung

\begin{tabular}{|c|c|c|c|c|c|c|c|}
\hline \multirow[t]{2}{*}{ Month } & \multicolumn{5}{|c|}{ Total As concentration $($ mean $\pm \mathrm{SD})$} & \multicolumn{2}{|c|}{ Inorganic As concentration (mean) } \\
\hline & Anpin & Putai & Tungshih & Wangkung & $\begin{array}{l}4 \text { townships } \\
\text { average (A) }\end{array}$ & $\begin{array}{l}4 \text { townships } \\
\text { average (B) }\end{array}$ & $(\mathrm{B}) /(\mathrm{A}) \%$ \\
\hline 1 & $12.39 \pm 1.24$ & $11.66 \pm 0.60$ & $-{ }^{\mathrm{a}}$ & - & $12.03 \pm 0.52$ & 0.293 & 2.433 \\
\hline 2 & $4.22 \pm 0.38$ & - & - & - & $4.22 \pm 0.38$ & 0.111 & 2.639 \\
\hline 3 & $7.60 \pm 0.73$ & - & $6.05 \pm 0.44$ & $7.55 \pm 1.25$ & $7.07 \pm 0.88$ & 0.086 & 1.219 \\
\hline 4 & $8.31 \pm 0.43$ & $22.90 \pm 7.41$ & $9.95 \pm 1.03$ & - & $13.49 \pm 8.24$ & 0.289 & 2.14 \\
\hline 5 & $7.15 \pm 1.08$ & $8.22 \pm 0.44$ & $8.95 \pm 0.69$ & $10.53 \pm 0.42$ & $9.01 \pm 1.06$ & 0.233 & 2.582 \\
\hline 6 & $8.51 \pm 2.90$ & $11.72 \pm 0.67$ & $10.37 \pm 0.96$ & $10.28 \pm 1.39$ & $9.89 \pm 1.93$ & 0.138 & 1.4 \\
\hline 7 & $7.50 \pm 0.51$ & $7.83 \pm 1.30$ & $8.55 \pm 0.94$ & $9.11 \pm 1.30$ & $8.51 \pm 0.52$ & 0.113 & 1.334 \\
\hline 8 & $8.37 \pm 0.33$ & $10.12 \pm 2.84$ & $8.63 \pm 0.79$ & $11.39 \pm 0.56$ & $9.42 \pm 1.70$ & 0.085 & 0.902 \\
\hline 9 & $8.12 \pm 0.24$ & $8.53 \pm 1.29$ & $9.44 \pm 2.72$ & $10.23 \pm 1.85$ & $9.15 \pm 0.86$ & 0.089 & 0.972 \\
\hline 10 & $6.77 \pm 1.28$ & $8.14 \pm 0.36$ & $9.53 \pm 2.25$ & $13.24 \pm 1.65$ & $9.74 \pm 2.41$ & 0.095 & 0.971 \\
\hline 11 & $7.62 \pm 1.64$ & $10.37 \pm 1.06$ & $7.07 \pm 1.78$ & $7.43 \pm 0.95$ & $8.13 \pm 1.51$ & 0.105 & 1.296 \\
\hline 12 & $7.38 \pm 0.49$ & $7.32 \pm 2.96$ & $8.63 \pm 0.65$ & $8.19 \pm 0.99$ & $7.88 \pm 0.63$ & 0.138 & 1.75 \\
\hline 12 month average & $7.90 \pm 1.80$ & $10.68 \pm 4.57$ & $8.71 \pm 1.30$ & $9.78 \pm 1.90$ & $9.09 \pm 3.08$ & 0.148 & 1.636 \\
\hline
\end{tabular}

${ }^{\mathrm{a}}$ Indicates no sample.

in April in Putai and in February in Anpin, respectively. The spatial concentration distributions (mean $\pm \mathrm{SD}$ ) of total As concentration in oysters were $7.90 \pm 1.80$, $10.68 \pm 4.57,8.71 \pm 1.30$ and $9.78 \pm 1.90 \mu \mathrm{g} / \mathrm{g}$ in Anpin, Putai, Tungshih and Wangkung, respectively (Table 1). Putai had the highest mean total As concentration whereas Anpin had the lowest. The result of the Scheffe test (Brace et al., 2000) indicates that the concentration of total As of oyster in Putai and Wankung significantly exceeds that in Anpin.

The seasonal concentration distributions (mean \pm SD) of total As in oyster are $9.32 \pm 4.69,9.58 \pm 1.90$, $8.85 \pm 2.29$ and $8.46 \pm 2.61$ in spring (March-May), summer (June-August), fall (September-November) and winter (December-February), respectively (Table 2). The results of the Scheffe test show the total As concentration in oysters does not vary significantly among the four seasons $(p>0.005)$.

Sanchez-Rodas et al. (2002) analyzed the same species of oyster (C. gigas) farmed off the Atlantic coast of Spain and showed that the total As concentration (mean $\pm \mathrm{SD}$ ) in oyster was $17.24 \pm 0.25 \mu \mathrm{g} / \mathrm{g}$. Vilano and Rubio (2001) also analyzed the same species of oyster farmed in northwest Spain. They found a total As concentration (mean $\pm \mathrm{SD}$ ) in oyster of $9.74 \pm 0.37 \mu \mathrm{g} / \mathrm{g}$. Kohlmeyer et al. (2002) examined the same species of oyster farmed in the Arcachon bay of France and found a total As concentration (mean $\pm \mathrm{SD}$ ) of $26.7 \pm 0.5 \mu \mathrm{g} / \mathrm{g}$.

The measured total As concentrations in oysters in the above studies all exceed the value herein of $9.09 \pm 3.08 \mu \mathrm{g} / \mathrm{g}$. In this work, the total As concentra-

Table 2

Seasonal concentration distribution of As species in oyster

\begin{tabular}{|c|c|c|c|c|}
\hline \multirow[t]{2}{*}{ As species } & \multicolumn{4}{|c|}{ As species concentration $($ mean $\pm \mathrm{SD}(\mu \mathrm{g} / \mathrm{g}))$} \\
\hline & Spring $(60)^{\mathrm{a}}$ & Summer (72) & Fall (72) & Winter (42) \\
\hline $\operatorname{As}(\mathrm{III})$ & $0.125 \pm 0.169$ & $0.071 \pm 0.048$ & $0.062 \pm 0.053$ & $0.107 \pm 0.077$ \\
\hline $\mathrm{As}(\mathrm{V})$ & $0.087 \pm 0.135$ & $0.046 \pm 0.053$ & $0.038 \pm 0.040$ & $0.055 \pm 0.052$ \\
\hline MMA & $0.124 \pm 0.163$ & $0.065 \pm 0.059$ & $0.099 \pm 0.132$ & $0.052 \pm 0.065$ \\
\hline DMA & $0.475 \pm 0.411$ & $0.385 \pm 0.277$ & $0.305 \pm 0.261$ & $0.444 \pm 0.247$ \\
\hline Total As & $9.323 \pm 4.687$ & $9.576 \pm 1.899$ & $8.852 \pm 2.290$ & $8.456 \pm 2.601$ \\
\hline Inorganic $\mathrm{As}^{\mathrm{b}} /$ Total As $(\%)$ & 2.27 & 1.22 & 1.13 & 1.92 \\
\hline
\end{tabular}

\footnotetext{
a The number inside the parentheses denotes the sample number.
}

${ }^{\mathrm{b}}$ Inorganic As is the summation of $\mathrm{As}(\mathrm{III})$ and $\mathrm{As}(\mathrm{V})$. 
Table 3

Concentration distribution of As species in oyster of four townships

\begin{tabular}{lcllll}
\hline Arsenic species & \multicolumn{4}{l}{ As species concentration (mean $\pm \mathrm{SD}(\mu \mathrm{g} / \mathrm{g}))$} \\
\cline { 2 - 6 } & Anpin $(72)^{\mathrm{a}}$ & Putai (60) & Tungshih (60) & Wangkung (54) & 4 township average (246) \\
\hline $\mathrm{As}(\mathrm{III})$ & $0.073 \pm 0.054$ & $0.145 \pm 0.151$ & $0.084 \pm 0.034$ & $0.071 \pm 0.038$ & $0.091 \pm 0.104$ \\
$\mathrm{As}(\mathrm{V})$ & $0.057 \pm 0.067$ & $0.062 \pm 0.032$ & $0.044 \pm 0.018$ & $0.032 \pm 0.016$ & $0.057 \pm 0.083$ \\
$\mathrm{MMA}$ & $0.084 \pm 0.095$ & $0.106 \pm 0.066$ & $0.068 \pm 0.032$ & $0.050 \pm 0.030$ & $0.084 \pm 0.112$ \\
DMA & $0.272 \pm 0.195$ & $0.443 \pm 0.371$ & $0.446 \pm 0.096$ & $0.480 \pm 0.075$ & $0.480 \pm 0.313$ \\
Total As & $7.90 \pm 1.80$ & $10.68 \pm 4.57$ & $8.71 \pm 1.30$ & $9.78 \pm 1.90$ & $9.09 \pm 3.08$ \\
Inorganic As $\mathrm{b} /$ Total As (\%) & 1.65 & 1.94 & 1.47 & 1.05 & 1.64 \\
\hline
\end{tabular}

a The number inside the parenthesis denotes the sample number.

${ }^{\mathrm{b}}$ Inorganic As is the summation of $\mathrm{As}(\mathrm{III})$ and $\mathrm{As}(\mathrm{V})$.

tions in oysters from the four townships varied significantly. A spatial variation in total As concentration in oysters is clearly evident.

Han et al. (1997, 1998) measured the total As concentrations in oysters in Putai, finding values of $12.3-21.4 \mu \mathrm{g} / \mathrm{g}$ in 1997 with a geometric mean of 18.7 $\mu \mathrm{g} / \mathrm{g}$, and 3.15-7 $\mu \mathrm{g} / \mathrm{g}$ in 1998 with a geometric mean of $4.86 \mu \mathrm{g} / \mathrm{g}$. The total arsenic concentration of oyster in Putai in this study ranged from 3.11 to $33.37 \mu \mathrm{g} / \mathrm{g}$ with a geometric mean of $9.99 \mu \mathrm{g} / \mathrm{g}$, suggesting that an annual temporal effect may apply. However, the seasonal variation of the total As concentration in oysters was statistically insignificant.

The annual average inorganic As was found to constitute $1.64 \%$ of the total As in oyster (Table 1). The highest and lowest percentages were $2.64 \%$ and $0.90 \%$, in February and August, respectively. The spatial inorganic As fractions in Anpin, Putai, Tungshih and Wangkung were 1.65, 1.94, 1.47 and $1.05 \%$, respectively (Table 3 ). The inorganic As fractions in spring, summer, fall and winter were $2.27,1.22,1.13$ and $1.92 \%$, respectively (Table 2). Edmonds and Francesconi (1993) reported that $1.4 \%$ of the arsenic

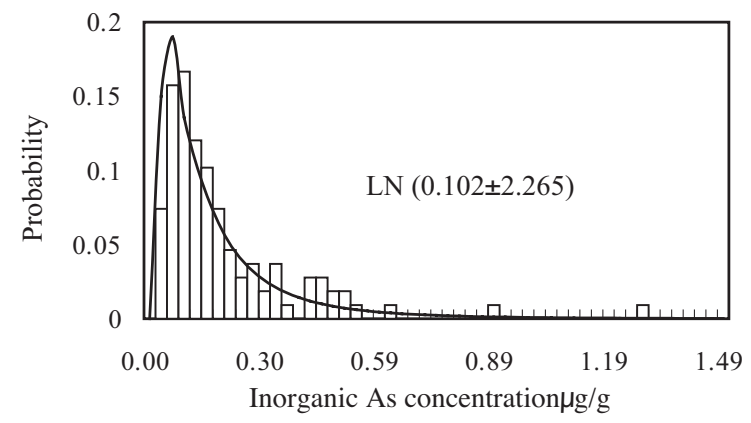

Fig. 3. Goodness-of-fit of lognormal distribution function LN (mean $\pm \mathrm{SD})$ of inorganic As concentration in oyster. in oysters (C. gigas) from Japan was inorganic As. Kohlmeyer et al. (2002) showed 3\% of the arsenic in oysters (C. gigas) from the northwest of Spain was inorganic. Our result of $1.64 \%$ is between these values for Japan and Spain.

Fig. 3 plots the determined goodness-of-fit of the lognormal probability function LN (mean \pm SD) of inorganic As concentrations ( $\mu \mathrm{g} / \mathrm{g}$ dry weight), based on the measured arsenic concentrations in oysters from the oyster farms of the four townships. The goodnessof-fit of the lognormal probability functions of the inorganic As concentration ( $\mu \mathrm{g} / \mathrm{g}$ dry weight) in oysters from the four townships in the four seasons is also determined. These determined lognormal probability functions were used to assess the risks to human health. The 18.6 and $56 \mathrm{~g} /$ day oyster ingestion rates of adults in Taiwan were used. Notably, $18.6 \mathrm{~g}$ is the mass of oyster in a typical fried oyster pancake, which is commonly served as a Taiwanese snack. Table 4 shows that the 95th percentile target cancer risk from ingesting inorganic As by eating 18.6-56 g/day of oyster in Taiwan is $1.26 \times 10^{-5}-3.82 \times 10^{-5}$. The 95 th percentile cancer risks were $1.30 \times 10^{-5}-4.30 \times 10^{-5}$,

Table 4

Estimated target cancer risk (TR) and target hazard quotient of inorganic As due to consumption of oyster produced in the southwest Taiwan (THQ)

\begin{tabular}{|c|c|c|c|c|}
\hline \multirow{3}{*}{$\begin{array}{l}\text { Cumulative probability } \\
\text { percentile }\end{array}$} & \multicolumn{4}{|c|}{ Ingestion rate } \\
\hline & \multicolumn{2}{|l|}{$18.6 \mathrm{~g} / \mathrm{d}$} & \multicolumn{2}{|l|}{$56 \mathrm{~g} / \mathrm{d}$} \\
\hline & TR & THQ & TR & THQ \\
\hline $5 \%$ & $9.00 \mathrm{E}-07$ & 0.005 & $2.80 \mathrm{E}-06$ & 0.015 \\
\hline $25 \%$ & $2.18 \mathrm{E}-06$ & 0.012 & $6.70 \mathrm{E}-06$ & 0.037 \\
\hline $50 \%$ & $3.73 \mathrm{E}-06$ & 0.021 & $1.11 \mathrm{E}-05$ & 0.062 \\
\hline $75 \%$ & $6.21 \mathrm{E}-06$ & 0.034 & $1.83 \mathrm{E}-05$ & 0.102 \\
\hline $95 \%$ & $1.26 \mathrm{E}-05$ & 0.071 & $3.82 \mathrm{E}-05$ & 0.214 \\
\hline
\end{tabular}


$1.86 \times 10^{-5}-5.6 \times 10^{-5}, 7.92 \times 10^{-6}-2.48 \times 10^{-5}$ and $1.01 \times 10^{-5}-3.03 \times 10^{-5}$, respectively, for Anpin, Putai, Tungshih and Wangkung. The estimated target cancer risks from ingesting inorganic As by consuming oysters all exceeded $10^{-6}$, and the risk was highest in Putai. Notably, Putai is the area in the southwest of Taiwan that saw a hyperendemic blackfoot disease.

Han et al. (1998) assumed that inorganic As represented $10 \%$ of total As in oyster. The highest target cancer risk that they estimated was $5.10 \times 10^{-4}$, associated with a intake of a $19.3 \mu \mathrm{g} / \mathrm{g}$ dry weight As content oyster and consuming $139 \mathrm{~g} /$ day for 30 years. The mean cancer risk for consuming $18.6 \mathrm{~g}$ /day of oysters in Taiwan is $3.2 \times 10^{-5}$ and the mean cancer risks in Anpin and Putai are $3.46 \times 10^{-5}$ and $1.71 \times 10^{-5}$, respectively. Their results are higher than those in this study, because of the $10 \%$ inorganic As content, the high ingestion rate ( $139 \mathrm{~g} /$ day) and the failure to convert the dry weight As to wet weight As in oysters. The estimated cancer risk herein is obtained under conditions that more closely resemble reality. Additionally, Gagnon et al. (2004) estimated the target cancer risk of inorganic As consumed in shellfish harvested from the north shore of the St. Lawrence River's lower estuary. They used the same assessment method and estimated a TR of $3.75 \times 10^{-5}$, given a $17 \mathrm{~g}$ daily consumption rate of soft-shell clams (Mya arenaria). Their results are compatible with those in this study.

Table 4 presents the target hazard quotient of the 5 , $25,50,75$ and 95 th percentiles of cumulative probability, from ingesting inorganic As by consuming 18.6 $\mathrm{g}$ /day of oysters. The 95 th percentile target hazard quotients from ingesting inorganic As by consuming $18.6-56 \mathrm{~g} /$ day oyster in Taiwan were 0.071-0.214. The 95th percentile target hazard quotients were 0.075-0.026, 0.104-0.314, 0.047-0.139 and 0.0560.169 in Anpin, Putai, Tungshih and Wangkung, respectively. The estimated target hazard quotients from ingesting inorganic As through oyster consumption were all below the acceptable safe value of unity. The highest target hazard quotient was found in Putai.

If a 95th percentile TR value of $10^{-6}$ is an acceptable risk, then the corresponding recommended daily ingestion rate of oyster can be calculated by Eq. (1). The inorganic As concentration (mean \pm SD) $0.019 \pm$ $0.017 \mu \mathrm{g} / \mathrm{g}$ (wet weight) in oyster is used, and the calculated daily ingestion rate of oyster is $1.6 \mathrm{~g}$. This is about one tenth of the mass of oysters in a fried oyster pancake. Restated, people in Taiwan should eat no more than three fried oyster pancakes per month to have an acceptable health cancer risk $\left(10^{-6}\right)$ from exposure to inorganic arsenic through oyster consumption.

\section{Conclusions}

This study directly measured the concentration of As species in oyster, to estimate the cancer and noncancer health risks associated with exposure to As through oyster consumption in Taiwan. 254 oyster samples of oyster were collected monthly from four townships in the southwest coastal area in 2002. The work lasted for 12 months and the collected samples covered $90 \%$ of the oyster production area. Among the four townships the measured mean concentrations of total As, As(III) and As(V) were 9.09, 0.09 and $0.06 \mu \mathrm{g} / \mathrm{g}$, respectively. The mean ratio of inorganic As to total As in oyster was $1.64 \%$. The distribution of inorganic As in oyster was determined by the goodness-of-fit of a lognormal function. Using the bestfitted lognormal function of inorganic As concentration in oyster, the estimated 95th percentile cancer risks are $1.26 \times 10^{-5}$ and $3.82 \times 10^{-5}$ for ingestion of $18.6 \mathrm{~g} /$ day and $56 \mathrm{~g} /$ day oyster which all exceeds the acceptable cancer risk of $10^{-6}$. Additionally, the estimated 95th percentile target hazard quotients were 0.071 and 0.214 for consumption of 18.6 and $56 \mathrm{~g} /$ day oyster. These values were both below unity and within the safety range for human health. Comprehensive data on inorganic As data in oyster were obtained herein and the estimated TR and THQ values adequately represent the health risk under realistic conditions. Based on the TR model estimation, an maximum ingestion rate of $1.6 \mathrm{~g} /$ day is recommended to ensure that people who ingest inorganic As by consuming oysters in Taiwan meet the 95th percentile carcinogenic risk, $10^{-6}$.

\section{Acknowledgements}

We thank the National Science Council of the Republic of China for financially supporting this research under Contract No. NSC 91-2313-B-002-270. 
We also thank Dr. Dipankar Chakraborti and Dr. Amitava Mukherjee for their constructive comments.

\section{References}

Brace, N., Kemp, R., Snelgar, R., 2000. SPSS for psychologists: a guide to data analysis using SPSS for Windows. Houndmills, Basingstoke, Hmpshire RG21 6XS and London, Macmillan Press Ltd.

Chan PC, Huff J. Arsenic carcinogenesis in animals and in humans: mechanistic, experimental, and epidemiological evidence. Environmental Carcinogenesis \& Ecotoxicology Reviews 1997; 15(2):83-122.

Chen CJ, Wu MM, Lee SS, Wang JD, Cheng SH, Wu HY. Atherogenicity and carcinogenicity of high-arsenic well water: multiple risk factors and related malignant neoplasms of blackfoot disease. Arterosclerosis 1988;8:452-60.

Chen CJ, Chen CW, Wu MM, Kuo TL. Cancer potential in liver, lung bladder and kidney due to ingested inorganic arsenic in drinking water. British Journal of Cancer 1992:888-92.

Chen SL, Dzeng SR, Yang MH, Chiu KH, shieh GM, Wai CM. Arsenic species in groundwaters of the blackfoot disease area, Taiwan. Environmental Science and Technology 1994;28: $877-81$.

Chen CL, Hsueh YM, Tseng MP, Lin YC, Hsu LI, Chou WL, et al, 2001. In: Chappell WR, Abernathy CO, Calderon RL, editors. Arsenic exposure and health effects IV. Oxford, UK: Elsevier; 2001. p. 13-143.

Ch'i IC, Blackwell RO. A controlled retrospective study of blackfoot disease, an endemic peripheral gangrene disease in Taiwan. American Journal of Epidemiology 1968;88:7-24.

Cullen WR, Reimer K. Arsenic speciation in the environment. Chemical Reviews 1989;89:713-64.

Edmonds JS, Francesconi KA. Transformations of arsenic in the marine environment. Experientia 1987;43:553-7.

Edmonds JS, Francesconi KA. Arsenic in seafoods: human health aspects and regulations. Marine Pollution Bulletin 1993;26: $665-74$.

Edmonds JS, Shibata Y, Francesconi KA, Rippington RJ, Morita M. Arsenic transformations in short marine food chains studies by HPLC ICP MS. Applied Organometallic Chemistry 1997;11: $281-7$.

Franceskoni KA, Kuehnelt D. Arsenic compounds in the environment. In: Frakenberger Jr WT, editor. Environmental chemistry of arsenic. New York: Marcel Dekker; 2002. p. 51-4.

Gagnon F, Tremblay T, Rouette J, Cartier JF. Chemical risks associated with consumption of shellfish harvested on the north shore of the St Lawrence River's lower estuary. Environmental Health Perspectives 2004;112:883-8.

Gomez-Ariza JL, Sanchez-Rodas D, Giraldez I, Morales E. Comparison of biota sample pretreatments for arsenic speciation with coupled HPLC-HG-ICP-MS. Analyst 2000;125(3):401-7.

Guo HR. Cancer risk assessment for arsenic exposure through oyster consumption. Environmental Health Perspectives 2002; 110:123-4.
Han BC, Jeng WL, Jeng MS, Kao LT, Meng PJ, Huang YL. Rockshells (Thais clavigera) as an indicator of $\mathrm{As}, \mathrm{Cu}$, and $\mathrm{Zn}$ contamination on the Putai Coast of the black-foot disease area in Taiwan. Archives of Environmental Contamination and Toxicology 1997;(32):456-61.

Han BC, Jeng WL, Chen RY, Fang GT, Hung TC, Tseng RJ. Estimation of target hazard quotients and potential health risks for metals by consumption of seafood in Taiwan. Archives of Environmental Contamination and Toxicology 1998;5(4): $711-20$.

Han BC, Jeng WL, Hung TC, Ling YC, Shieh MJ, Chien LC. Estimation of metal and organochlorine pesticide exposures and potential health threat by consumption of oysters in Taiwan. Environmental Pollution 2000;(109):147-56.

Hsueh YM, Wu WL, Huang YL, Chiou HY, Tseng CH, Chen CJ. Low serum carotene level and increased risk of ischemic heart disease related to long-term arsenic exposure. Atherosclerosis 1998;(141):249-57.

Huang YK, Lin KH, Chen HW, Chang CC, Liu CW, Yang MH, et al. Arsenic species contents at aquaculture farm and in farmed mouthbreeder (Oreochromis mossambicus) in blackfoot disease hyperendemic areas. Food and Chemical Toxicology 2003; 41(11): 1491-500.

IARC. Arsenic and its compounds. International Agency for Research on Cancer 1980;23:39-141.

Kohlmeyer U, Kuballa J, Jantzen E. Simultaneous separation of 17 inorganic and organic arsenic compounds in marine biota by means of high-performance liquid chromatography/inductively coupled plasma mass spectrometry. Rapid Communications in Mass Spectrometry 2002;16:965-74.

Lin TH, Huang YL, Wang MY. Arsenic species in drinking water, hair, fingernails, and urine of patients with blackfoot disease. Journal of Toxicology and Environmental Health Part A 1998; 53:85-93.

Lipton J, Gillett GW. Uncertainty in ocean-dumping health-risks: influence of bioconcentration, commercial fish landings and seafood consumption. Environmental Toxicology and Chemistry $1991 ; 10: 967-76$.

Sánchez-Rodas D, Geiszinger A, Gomez-Ariza JL, Francesconi KA. Determination of an arsenosugar in oyster extracts by liquid chromatography-electrospray mass spectrometry and liquid chromatography-ultraviolet photo-oxidation-hydride generation atomic fluorescence spectrometry. Analyst 2002;127:60-5.

Suhendrayatna, Ohki A, Nakajima T, Maeda S. Studies on the accumulation and transformation of arsenic in freshwater organisms II Accumulation and transformation of arsenic compounds by Tilapia mossambica. Chemosphere 2002; 46(2):325-31.

Tseng CH, Tai TY, Chong CK, Tseng CP, Lai MS, Lin BJ, et al. Long-term arsenic exposure and incidence of non-insulin-dependent diabetes mellitus: a cohort study in arseniasis-hyperendemic villages Taiwan. Environmental Health Perspectives 2000;108:847-51.

U.S. EPA. Special report on ingested inorganic arsenic: skin cancer; nutritional essentiality. Washington, D.C.: U.S. Environmental Protection Agency; 1988. Risk Assessment Forum, EPA-25/3-87-13. 
U.S. EPA. Guidance manual for assessing human health risks from chemically contaminated, fish and shellfish. Washington, D.C.: U.S. Environmental Protection Agency; 1989. EPA-503/ 8-89-002.

U.S. EPA. Integrated risk information system (IRIS). Washington, D.C.: U.S. Environmental Protection Agency; 2003. Available: http://www.epa.gov/iris/.

U.S. EPA. Risk-based concentration table. Region 3, Philadelphia: U.S. Environmental Protection Agency; 2004.
U.S. FDA. Guidance document for arsenic in shellfish. Washington, D.C.: U.S. Food and Drug Administration; 1993. p. $25-7$.

Vilano M, Rubio R. Determination of arsenic species in oyster tissue by microwave-assisted extraction and liquid chromatography-atomic fluorescence detection. Applied Organometallic Chemistry 2001;15:658-66. 